\title{
Serbia and the fourth industrial revolution
}

\author{
Živojin B. Prokopović, Karolina S. Prokopović and Borivoje B. Prokopović \\ ${ }^{1} \mathrm{PhD}$ Business high school „Prokopović“", Niš, Serbia \\ ${ }^{2} \mathrm{PhD}$ Emeritus Business high school „Prokopović“", Niš, Serbia \\ E-mail: z.prokopovic@gmail.com
}

\begin{abstract}
Today the categories: technological innovation, productivity growth, changes in production organization, market liberalization, the changed role and importance of the state and consumerism, which has become the dominant cultural pattern, are increasingly being questioned. Taken together or individually, these categories have been celebrated over the past decades as an expression of the freedom that has been imposed as a fundamental value and measure of human progress. Since then, centuries have passed, and here we are in an era called the "Fourth Industrial Revolution." Serbia is well known to have missed two technological revolutions in the past almost three decades and would finally have to join the fourth. The transition to Industry 4.0, i.e. the complete digitization of complete industrial production, is a chance for faster economic growth, further dynamic export growth and job creation. The silent digital revolution is, therefore, underway in Serbia today, and it is closely watching this process.
\end{abstract}

Keywords: Innovations, productivity, changes, digitization, economic growth, the industrial revolution

\section{Introduction}

Serbia has arrived at the threshold of the 21 st century with sanctions almost destroyed by the economy, with decimated R\&D capacities, with little scientific activity, and with a massive exodus of young and promising staff. Naturally, it became a matter of survival and finding a way to catch up with the backward train of the Fourth Industrial Revolution, in order to become part of it, in the first place. And the fourth industrial revolution is the Internet and the networked economy, and despite the fact that Serbia started its digitalization only a few years ago, with the additional effort and careful, i.e. direct investment, the goal is achievable - economic development based on innovation and digitization. Serbia has a tradition of innovation, and it is very advantageous that close to one third of all students enroll in engineering faculties. We are following a trend, however we must continue to do so, because in the next ten to fifteen years there will be great change in the digital market. Great changes are expected in the job market, new professions will emerge and we can stay current only if this trend on our engineering faculties continues, and also improves.

The aim is to re-industrialize the country based on the development of national technology platforms, the digitization and deployment of robotics, artificial intelligence and the combination of mechanical engineering, information and communication technology (ICT) and electronics, all of which would create the conditions for new employment and stop the exodus of professionals. It is 
interesting to mention here the interview of our Prime Minister, given to the journalist Süddeutsche Zeitung, in which she emphasized that she wanted a revolution, now here and in the whole of Serbia, emphasizing that it should be a quiet, intelligent and democratic revolution, that is, a revolution of bits and of land-changing bytes. The Seventh Regional Summit of 100 Southeast European Business Leaders was held in Belgrade in October 2018, dominated by the topic of digital transformation and how to use the Fourth Industrial Revolution in the region, which is a huge chance for Serbia and other countries in the region to catch up with the developed world.

Although it is very difficult to make up for developmental gaps as technologies change day by day, we believe that, in the wake of the Fourth Industrial Revolution, marked by digitalization, the Western Balkans region can be a winner and a leader in the innovation and deployment of new technologies. In this regard, Serbia is on the right track, with gross domestic product (GDP) growth of 4.9 percent in the first half of this year (2018), which is one of Europe's fastest growing economies and expects growth by the end of the year above 4 percent. At the same time, Serbia is rapidly modernizing its education system, but is also working to strengthen digital competences so that, while teaching young generations how to solve problems, it will save them for the jobs they will work on in the future.

But according to Ivan Nikolic, editor of the Macroeconomic Analysis and Trends (MAT) newsletter, the current level of production is 44.2 percent lower than the 1990 average. Nikolic has calculated that we will have to wait for 2026 to emerge from the transition gap, when we will reach production levels from the beginning of the last decade of the last century. Does this mean that at this historic moment, Serbia will not need a new Ned Lud and a "ludic movement", like the one from the early 19th century Britain, in which workers were breaking machines trying to save their jobs and stop progress? It sounds ironic, but the development of our industry stopped at the beginning of 1990. Data show that in those years, the share of industrial production in gross domestic product (GDP) was 44.5 percent. Taking into account all changes in methodology, as well as the fact that these two amounts are not quite comparable, today the share of industry in gross domestic product (GDP), i.e. everything that the economy and citizens create in a year, is about 20 percent. Likewise, almost three decades ago (1990), more than one million workers worked in the Serbian industry, and today, about 400,000 employees have found their way into this branch of the economy.

Can Serbia, if we have already skipped the third one, directly jump into the Fourth Industrial Revolution? When asked by economist Miodrag Zec, he said that "There is no skipping history! We always try to skip the chasm, but most of the time we run into it. So, from communism, we wanted to jump directly into capitalism, so we broke into the abyss and arrived in Manchester-type capitalism, written by Karl Marx: can protect."

Dusko Vasiljevic, a World Bank expert, says the Global Development Report shows that countries like Serbia will have to adapt quickly to new changes in the labor market. Serbia has to do this by "... no longer emphasizing cheap labor as our comparative advantage. Because robotics squeezes out manipulative power and inexpensive work that can be replaced with a machine. Our advantage will have to be an educated and trained workforce as well as a good business environment. "In the spring of 2018, World Bank experts dusted off Capital, the most famous work of Karl Marx, whose first edition saw the light of day back in 1867. It seems unbelievable, but the economists of this financial organization start their latest Global Development Report some time ago (October 2018) with the old Marx quote: "Machines are not only superior competition to man, as surplus. Machines are the most powerful weapon for counteracting strikes." And the answer to the question why the sentences that Karl Marks wrote just over 150 years ago made the World Bank analysts current is hiding in the fact that the number of robots in the global industry is growing rapidly. This report states that at the end of 2015 , there were 1.6 million robots working worldwide, and that by the end of 2019, that number will reach 2.6 million. Robots and technology will continue to "replace workers" around the world, according to a World Bank report, noting that due to production automation, the number of industrial workers in the UK, the cradle of the Industrial Revolution, has fallen by a third from 1990 to 2016.

The World Bank estimates that 100,000 to two million jobs in Bolivia will be automated in the coming period. It warns of an even greater risk in developed economies. 


\section{Serbia's comparative advantages}

If Serbia skipped the third industrial revolution, could it then be our comparative advantage, because we shut down industrial jobs long before the world robot invasion of manufacturing plants.

Robots are thought to take over half of the jobs by 2025. Regardless of the fact that they embarked on an aggressive offensive into the labor market, the fact is that they are doing so much more slowly than previously thought at the beginning of the twentieth century. The famous economist John Maynard Keynes has predicted that robotics will so far enter all pores of life in 100 years that it will be enough for a man to work only three hours a day. That this forecast did not come true is the best proof that even the world's best economists sometimes make mistakes in their forecasts. Although more than half of existing jobs will be carried out by robots by 2025, it is still possible to create 58 million new jobs in the next five years, according to a report by the World Economic Forum Tanjug.

The development of technology, automation and artificial intelligence could cause a loss of 75 million jobs by 2022, but at the same time create 133 million new jobs, which means that the net result would be 58 million new jobs, according to a report titled " The Future of Jobs 2018, " CNBC reports. By 2025, more than half of existing workplace tasks will be performed by machines, compared to 29 percent today, according to the report. At the same time, there could be a significant shift in the quality, location and format of new jobs, which could lead to the potential termination of full-time permanent employment, the report said. Some companies will have the choice of hiring temporary workers, freelancers and specialized contractors, while others will be able to automate many business processes. Employees will also need a new set of skills and knowledge in this regard. There are plenty of futurologists working on these predictions and, according to the release, machines are expected to perform about 42 percent of all current workplace tasks by 2022. On the other hand, in the era of the 4th industrial revolution and global economic change, prominent economists and politicians also point to possible political changes. It is also interesting to note in this connection that one of the conclusions from the "Summer Davos" in Tianjin (2018) is that the Fourth Science and Technology Revolution brings with it the end of the unipolar and the beginning of the multipolar world. It is interesting, therefore, to look at the fourth technological revolution from a different angle - the appetite for the emergence of the global market, not only at the economic level, religion, and at the level of a combative civilization for transformation in the global globality. Earlier US administrative trends in early kinesiological use have identified a niche in the magnificent media, such as over-US domination, but more recently, Donald Trump has put emphasis on managing the problem. The Serbian war with China has begun, and you make your previous choice with the password "America in the first place," try to keep the helm of my white houses bright. on the other hand, Chinese Prime Minister Li Qingangang says that globalization is taking a toll on his country as well, because he believes that today is not a post-globalized world, but a globalization with a new multipolar sign and that this trend was initiated by China. It is certainly important for Serbia to recognize these trends in a timely manner and to incorporate them in a timely manner. In this regard, we point out in this place two lists that assess the level of competitiveness of our economy, according to which in this year's list of competitiveness of the World Economic Forum has advanced five places and took 65th position, while in the Doing business list. The World Bank fell by as many places and reached 48th position. For Serbia, all the lists that measure competitiveness and business conditions are very important because they show us the directions we need to move and what reforms we need to change.

The end of the one-centered world can also be a good opportunity to better position Serbia on the global stage. In this regard, it should be borne in mind that the new partners will behave differently in the future, and this brings with it new challenges that Serbia and its business world must face.

\section{Chances for Serbia}

The further development of the productive forces and the scientific and technological revolution are two historical factors that, at the beginning of the last century, announced new relationships that would affect both social development in developed countries and overall international politics and economic relations. What the previous industrial revolution meant for the development of productive forces and 
the full formation of production relations, the Fourth Scientific and Technological Revolution means the beginning of a new one in these relations - the beginning of the arrival of a new and richer society, a new civilization. The fourth industrial revolution creates the material basis for the development of society on a new basis - on the system of sustainable development. It, therefore, represents the material basis for the development of new production relationships, which are the global socioeconomic framework in which the present-day world, the world of sustainable development, is developing. But on a journey in the future by the train of the Fourth Industrial Revolution, the Serbian economy cannot start without academia and the state, because it does not suffer deliberation and indecision, and whoever does not join it will disappear from the market map of the world.

In order for Serbia to embark on the train of the technological future, also known as Industry 4.0, it is imperative that all of our businesses digitally transform important areas of their business: design, production, marketing, management, sales ... Because only those companies that follow innovate and have creative management teams, modern and automated manufacturing, upgraded with applications designed for potential power buyers on the train of the Fourth Industrial Revolution to count in a decent place. And a survey conducted in June 2018 by the Serbian Chamber of Commerce found that 60 percent of small and medium-sized businesses have no plans for digital transformation, nor do they understand why something would be useful. Such companies, however, make up 99 percent of the Serbian economy, which has led to:

*The first step is to organize training for digital consultants, so that twenty-five of them, who have received certificates, will help SMEs across Serbia in the digital transformation of their businesses. This creates the initial conditions for digitalization to enter the business of these companies.

*The second step is that the Government of Serbia, together with the Chamber of Commerce in 2019 , will start a new program that will identify a part of the economy - the industrial sector, which will extend to a larger number of small and medium-sized enterprises (the areas estimated to have the greatest potential to encourage economic development and then channel research and innovation). This is a higher stage in the implementation of new technologies (services: e-business, e-signature, ebanking...).

Each technological revolution is a new train, and Serbia has missed the previous one and it is not worth chasing after it, because it is faster than us. The new one, which represents the Fourth Industrial Revolution, we can wait at and board the station. The fact that we have only 500-600 robots today, and with about that many experts working on them, should not make us sad for the past, when our industry was developed and when more workers worked in this sector. During the 1980s Serbian industry designed and manufactured industrial robots, and numerically ran machines were mass exported around the world, including markets such as USA and Germany, which indicates that currently we are in a state of technological disrepair as well as unused opportunities. We do not need the traditional industry today, but rather we need to promote a new business model in order to be more attractive to competitors from other parts of the world to invest here. So any country, including Serbia, can skip the technological gap, and what we need is a well-packed promotional package to successfully introduce ourselves to the world. Otherwise, it should always be emphasized, Serbia has a much better human potential than we acknowledge and recognize; there are so many successful and smart people. Understandably, this should be the job of promoting everyone who regularly contacts the outside world: Ministry of Foreign Affairs, Trade, Chamber and others. In this regard, it is necessary to focus on several sectors: the start-up fund in business, communication technology, agriculture, automotive, mining and energy. Money is often not the most important. It is important for young people with innovative ideas to have enough passion to realize them. If there is not enough money in the state one should look for it elsewhere. Funds for innovative projects can be found in the Silicon Valley. Also, one can find funding in China to invest in new technologies. One should not expect the funds to appear out of nowhere. It is necessary for the entrepreneurs, the academy and the state to form a sort of operation group with the task of connecting young people with those who have funds to invest.

Serbia as a small country should change its behavior. We are as great as Singapore and, if that country could do what it did, it is up to us to focus and succeed. Otherwise, about 45,000,000 people 
in the IT sector are currently hired in Serbia, working on software for a variety of needs: from agriculture to medicine, as well as applications from many companies. Many of them are engaged in the development centers of the world's leading technology companies, including: Microsoft, IBM and Intel, which are already established in Serbia or have licensed services to local companies. Foreign capital has been behaving reserved since the start of the crisis in 2008, and given that there is still no significant economic recovery in Europe, investors are hesitant to invest.

But the crisis should not be an obstacle to our development. Namely, Serbia and its educational system must be brought closer to the economy. It is very important for students to spend as much time as possible in companies, especially in small and medium-sized companies, as they are the key to future economic development. In this regard, the 2017 initiative to launch IT retraining programs for both the unemployed and those without IT background proved successful. Currently, Serbia is lacking 15,000 IT experts, however with support, overall effects in this field could be much better, which would be visible in greater export and greater production of value in the IT field.

It is the trends that keep us going and forcing us to change. The new challenges and similar innovations brought by the digital age, contemporary needs and consumer habits must already be answered by the traditional industry. Otherwise, startup companies with their innovative solutions have a serious potential to take away a large chunk of the market cake.

Key changes will come by transforming big companies in the future, as the world changes, so do habits, needs, and even consumer expectations. The way business communicates today is also changing.

\section{Conclusion}

There have been many argumentative examples from which the contours of future business can be clearly recognized, which will exclusively acknowledge the consumption of "gray matter" and the overall achievement of science and cumulative knowledge. Our country has the same chances as other countries in the world, especially since we have enormous scientific and professional potential, which should be integrated and integrated into a single information system, which would then register where what is done in science and where it is done. One of the solutions of further development is the establishment of a "core of knowledge" in which most of Serbia's scientific potential will be concentrated. It does not matter where it will be located, because the real scientist does not even ask such a question. The only knowledge he does not know: borders, customs and various other obstacles, so for the first time it could be university centers such as Belgrade, Nis, Novi Sad and Kragujevac.

\section{References}

[1] Barney, J. (1997). Gaining and Sustaining Competitive Advantage. Jersey: Prentice Hall.

[2] Dragičević, A., Dragičević D. (2003). Doba kiberkomunizma [The age of cyber communism]. Zagreb.

[3] Drucker, F. Piter. (1980). Managing in Turbulent time, Harper \& Row, New York.

[4] Drucker, F. Piter. (1989). The New Realities. New York: Harper \& Row.

[5] Drucker, F. Piter. (1995). Post kapitalističko društvo [Post capitalist society]. Belgrade: Grmeč i Privredni pregled.

[6] Ištvan, Č. (2000). Uvod u teoriju globalnog razmišljanja [Introduction to the theory of global thinking]. Novi Sad: Prometej.

[7] Milivojević, Ž., Damnjanović A., Milovanović, S. Povećanje konkuretnosti preduzeća investiranjem $u$ inovacije $i$ nove tehnologije [The increase of bussines competitivness by investing in inovative and new technologies]. Niš: Ekonomika no. 4/15

[8] Prokopović, B.B., Prokopović, B.B., Prokopović, B.Ž. (2016). Pitanje svih pitanja za Srbiju u 2016. godini je reforma preduzeća u državnom vlasništvu [The question of all questions for Serbia in 2016 is the reform of state owned companies]. Niš: Ekonomika no. 3/16

[9] Harold, R.F. (2003). An Assay in Dinamic Theory. The Economic journal jun/89. i Evsey.

[10] Westland, C. (2002). Valuing Technology. John Wiley \& Sons, Pte Ltd. 